\title{
A ADPF 153 e o Caso Herzog: Uma Justiça de Transição à Brasileira
}

\author{
Adriele Priscila Sales Aragão \\ Bacharel em Direito pela Universidade Federal do Amapá. Assessora na Defensoria Pública do Estado do Amapá no Núcleo de Execu- \\ ção Penal. http://lattes.cnpq.br/1242357694202311. adrisalesss@gmail.com \\ Daize Fernanda Wagner \\ Doutora em Direito pela Universidade Federal de Minas Gerais. Mestre em Direito pela Ludwig-Maximilians-Universität München. \\ Bacharel em Ciências Jurídicas e Sociais pela Pontifícia Universidade Católica do Rio Grande do Sul. Professora-adjunta na Universida- \\ de Federal do Amapá, lotada no curso de Direito e colaboradora no Programa de Pós-Graduação em Estudos de Fronteira. Líder do \\ grupo de pesquisa Unifap/CNPQ Direitos Humanos, Cidadania e Justiça. http://lattes.cnpq.br/8232540501482095. \\ daizefernandawagner@gmail.com
}

RESUMO

Partindo da ideia de que o Supremo Tribunal Federal estaria se omitindo de cumprir a função de controle de convencionalidade, o que geraria embaraços à Justiça de transição brasileira, este artigo tem como objetivo investigar a Arguição de Descumprimento de Preceito Fundamental 153 e o Caso Herzog, objeto de decisão da Corte Interamericana de Direitos Humanos. Para tanto, utilizou o conceito de controle de convencionalidade e a perspectiva do Direito Internacional dos Direitos Humanos nos respectivos casos. Como metodologia principal, a investigação é jurídico-propositiva, com abordagem qualitativa e pesquisa bibliográfica. Os resultados demonstraram que o STF ignora o debate internacional sobre a internacionalização do direito interno, confirmando a hipótese.

Palavras-chave: Caso Herzog. Supremo Tribunal Federal. Direito Internacional dos Direitos Humanos. Corte Interamericana de Direitos Humanos. Justiça de transição.

\section{ADPF 153 AND CASE OF HERZOG: A BRAZILIAN TRANSITIONAL JUSTICE}

\section{ABSTRACT}

Assuming the idea that the Brazilian Federal Supreme Court would be omitting its function of comply with conventionality control, which would create embarrassment to the brazilian transitional justice, this article aims to investigate the Claim of Breach of Fundamental Precept 153 and the Case of Herzog, a recent decision of the Inter-American Court of Human Rights. Therefore, it resorts the doctrine of conventionality control and the perspective of the International Law of Human Rights in the respective cases. The main methodology was based on legal-purpose study, qualitative approach and bibliographic research. The results showed that the Brazilian Federal Supreme Court ignores the international debate on the internationalization of domestic law, confirming the hypothesis.

Keywords: Case of Herzog. Brazilian Federal Supreme Court. International Law of Human Rights. Inter-American Court of Human Rights. Transitional justice.

\section{SUMÁRIO}

1 Introdução. 2 A Arguição de Descumprimento de Preceito Fundamental N. 153. 2.1 A ADPF 153 à Luz do Direito Internacional dos Direitos Humanos. 3 Caso Herzog vs. Brasil. 3.1 O Sistema Interamericano de Direitos Humanos e o Direito Interno. 3.2 Direitos Violados no Caso Herzog. 4 Justiça de Transição. 4.1 Justiça de Transição à Brasileira. 4.2 Onde Está o Controle de Convencionalidade? 5 Considerações Finais. 6 Referências. 


\section{INTRODUÇÃO}

Assim começa o fascismo. Ele não diz nunca seu nome, ele ascende, escala. Quando mostra a ponta de seu nariz, dizemos: É ele? Acham mesmo? Não é preciso exagerar. E um dia ele se enfia pela goela e é muito tarde para expulsá-lo (GIROUD, 1997).

São Paulo, 24 de outubro de 1975. Dois agentes do Destacamento de Operações de Informação - Centro de Operações de Defesa Interna (DOI-Codi) entram na sede da TV Cultura e intimam Vladimir Herzog. Na manhã seguinte, Vladimir comparece voluntariamente no destacamento. É algemado, interrogado e torturado. Seus colegas jornalistas, também detidos no mesmo local, Leandro Konder e George Duque Estrada, ouvem os gritos na sala ao lado. Às $15 \mathrm{~h}$ do mesmo dia, é supostamente encontrado morto por seus carcereiros e torturadores. Vladimir teria se enforcado com o cinto do macacão de presidiário - cinto esse inexistente, de acordo com os companheiros de prisão (CORTE..., 2018).

Vladimir Herzog, nascido Vlado Herzog, originário da antiga lugoslávia, hoje Croácia, era filho de judeus. Sua família refugiou-se no Brasil em decorrência da perseguição sofrida pelo regime nazista de Hitler. No Brasil foi jornalista, dramaturgo e professor da Universidade de São Paulo (BRASIL, 2007). Dez anos antes de seu assassinato, seu nome já aparecia em relatórios de departamentos de vigilância e de acordo com esses documentos, Herzog seria contra o "movimento revolucionário de 64". Em 1966 mudou-se para a Inglaterra e lá teve dois filhos com Clarice, sua mulher: Ivo e André. Trabalhava na BBC quando decidiu voltar ao Brasil mesmo em meio ao caos. "É preciso tentar", disse Herzog a amigos por meio de cartas (MARKUN, 2015). Em 1968, o ano de sua volta, foi instaurado o Al-5.

Após a morte de Herzog, jornalistas de São Paulo paralisaram suas atividades. Houve grande comoção nacional. A missa de sétimo dia, na Catedral da Sé em São Paulo, reuniu cerca de 8 mil pessoas, um dos maiores atos durante a ditadura. Dom Paulo Evaristo Arns, arcebispo de São Paulo e um dos responsáveis pela missa, afirmou que foi intimidado por dois comissários do governo a não presidir o ato, pois haveriam mais de 500 policiais na praça com ordem de atirar ao primeiro grito (JORDÃO, 1979). Apesar disso, o evento ocorreu em silêncio e com grande cobertura da imprensa.

$O$ assassinato de Vladimir foi um marco no regime e no processo de abertura democrática. A versão oficial de que sua morte teria sido suicídio não foi aceita em nenhum momento. Tradicionalmente, no judaísmo, seu corpo deveria ter sido enterrado em uma área especial do cemitério - o que não ocorreu, apesar de em seu atestado de óbito, assinado pelo médico Harry Shibata, constar como causa mortis o suicídio (BRASIL, 2007). A família de Vlado, como era conhecido entre os mais íntimos, começou então uma luta pelo reconhecimento dos crimes cometidos pelo Estado brasileiro.

Partindo do Caso Herzog, o presente artigo tem como problema o questionamento acerca da maneira pela qual o poder Judiciário tem proferido decisões em casos de crime lesa-humanidade cometidos durante o regime ditatorial militar, sob a perspectiva do Direito Internacional dos Direitos Humanos. A hipótese é de que esse mesmo poder, mais especificamente o Supremo Tribunal Federal (STF), tem se omitido da função de exercer controle de 
convencionalidade nos seus julgamentos. Além disso, tem fundamentado suas decisões em direção contrária aos tratados de direitos humanos, dos quais o Brasil é signatário, e contra as instâncias internacionais e suas jurisprudências, às quais o Estado é subordinado, considerando-se o conceito de controle de convencionalidade.

Este trabalho, portanto, tem como objetivo geral analisar tanto a decisão do STF na Arguição de Descumprimento de Preceito Fundamental (ADPF) n. 153, quanto a decisão da Corte Interamericana de Direitos Humanos (CORTE..., 2018) no Caso Herzog. Como objetivos específicos, visa a verificar se a ADPF n. 153 utilizou uma interpretação conforme a jurisprudência e as normas internacionais, e explorar o conceito de Justiça de Transição no meio jurídico, retomando o debate por meio da ADPF n. 153 e do Caso Herzog.

O uso do conceito de Justiça de Transição neste artigo faz-se necessário tanto pela sentença da Corte Interamericana de Direitos Humanos, que tem como um dos focos o direito à verdade aos cidadãos brasileiros, quanto pela ADPF n. 153, que impossibilitou a persecução penal dos agentes de Estado. Tanto memória e verdade, como persecução penal, são pilares para uma Justiça transicional, como será visto adiante. Paradoxalmente, os dois momentos principais da tramitação processual do Caso Herzog (na Justiça brasileira e na internacional) foram marcados por decisões do Executivo e Judiciário brasileiros contra a jurisprudência do Direito Internacional dos Direitos Humanos (respectivamente, a Lei 6.683/79 e a ADPF n. 153).

Seguindo metodologia proposta por Gustin e Dias (2010), o artigo parte da vertente jurídico-dogmática, pois tem como foco os elementos interpretativos do ordenamento jurídico e desenvolve a investigação com vista à compreensão das relações normativas entre o Direito Interno brasileiro e o Direito Internacional dos Direitos Humanos. Quanto à investigação, a pesquisa tem duas abordagens principais: histórico-jurídica e jurídico-propositiva. A utilização de fontes históricas é feita não somente para fins de informação, mas também de formação de conceitos, compreensão e contexto para o entendimento da inconstitucionalidade da Lei de Anistia (Lei 6.683/79) e dos abusos ocorridos no Caso Herzog. Já a investigação jurídico-propositiva destina-se a questionar a Lei 6.683/79 e a jurisprudência do STF e tem como objetivo propor mudanças na interpretação da lei. Assim, pode ser classificada como uma pesquisa que utiliza a abordagem qualitativa, por meio da investigação bibliográfica.

\section{A ARGUIÇÃO DE DESCUMPRIMENTO DE PRECEIO FUNDAMENTAL N. 153}

Os movimentos a favor da anistia iniciaram-se nos primeiros anos de perseguições políticas do regime autoritário de 1964, no entanto, após o sufocamento da oposição, apenas em 1975, com a criação do Movimento Feminino pela Anistia, é que o Brasil ganhou um novo fôlego na luta pelos perseguidos políticos. Como afirmado por Lins e Silva (2011), outras ações foram surgindo após 1975, como a publicação de um dossiê pelo Comitê Pró-Amnistia Geral no Brasil, de Lisboa (Portugal), e em 1976, a aprovação de uma moção pela Anistia, durante a 28a Reunião Anual da Sociedade Brasileira para o Progresso da Ciência (SBPC). Não é exagero afirmar que a morte de Herzog foi um evento catalisador para a insurgência desses movimentos.

Durante o trâmite, contudo, e até a promulgação da Lei de Anistia, seu texto original foi modificado. A ânsia por ser uma anistia ampla, geral e irrestrita não foi suprida. Ao contrário, a lei restringiu sua eficácia, não alcançando os subversivos que já haviam sido condenados - 
condenação essa sem o devido processo legal, com confissões sob tortura e sem o direito ao contraditório. Além disso, o $§ 1^{\circ}$ do artigo 10 da lei refere crimes conexos, conforme a seguir transcrito:

Art. $1^{\circ}$. É concedida anistia a todos quantos, no período compreendido entre 02 de setembro de 1961 e 15 de agosto de 1979, cometeram crimes políticos ou conexos com estes, crimes eleitorais, aos que tiveram seus direitos políticos suspensos e aos servidores da Administração Direta e Indireta, de fundações vinculadas ao poder público, aos Servidores dos Poderes Legislativo e Judiciário, aos Militares e aos dirigentes e representantes sindicais, punidos com fundamento em Atos Institucionais e Complementares.

$\S 10$ - Consideram-se conexos, para efeito deste artigo, os crimes de qualquer natureza relacionados com crimes políticos ou praticados por motivação política (BRASIL, 1979) (grifamos).

Esse é o ponto principal do qual parte a discussão acerca do alcance da anistia conferida pela lei. Tal discussão perdurou por décadas, até a proposição da ADPF n. 153, pois a extensão do que estaria abrangido no conceito de crimes conexos é obscura, causando confusão na aplicação da lei.

Em 2008, o Conselho Federal da Ordem dos Advogados do Brasil (OAB) ajuizou a ADPF n. 153. De acordo com Silva (2006), a ADPF é um meio de invocar a prestação jurisdicional em defesa de direitos fundamentais. Ainda conforme o autor, a expressão "preceito fundamental" tem um sentido muito mais abrangente que "princípios fundamentais", pois é o sentido básico do sistema constitucional.

De acordo com a petição inicial, a ação ajuizada teve como base o $\S 10$ do artigo 10 da Lei $6.683 / 79$, sob a justificativa de que haveria controvérsia constitucional. $O$ texto em questão afirma que crimes conexos são aqueles de qualquer natureza relacionados com crimes políticos ou praticados por motivação política. Logo, o Conselho Federal da OAB buscava que a Corte realizasse uma interpretação conforme os preceitos constitucionais, a fim de que crimes comuns cometidos por agentes militares durante a ditadura, como os de homicídio, atentado violento ao pudor ou até mesmo estupro, não fossem abrangidos pela anistia.

O julgamento ocorreu menos de dois anos após a propositura da inicial pelo Conselho. Segundo Meyer (2012), a inclusão da ADPF n. 153 na pauta de julgamento do STF ocorreu em tempo recorde, se comparado a outros temas de relevância para a sociedade brasileira. "A ADPF n. 54/DF, que reconheceu a constitucionalidade da antecipação do parto por anencefalia fetal, [por exemplo], levou oito anos para ser julgada" (MEYER, 2012, p. 52). O que parece é que a inevitável condenação na Corte IDH no Caso Gomes Lund, que veio um ano depois, pesou para que o julgamento fosse antecipado. Assim, a Corte pôde votar o tema sem a pressão de uma condenação internacional direta sobre o tema. A consequência dessa antecipação foi um debate sem a participação da sociedade civil, o que resultou em reflexões mais rasas em torno do tema.

A decisão final na ADPF n. 153 foi pela improcedência da arguição, por maioria de sete votos, em conformidade com o voto do relator, ministro Eros Grau. Acompanharam seu entendimento as ministras Carmen Lúcia e Ellen Gracie e os ministros Gilmar Mendes, Marco Aurélio, Celso de Mello e Cezar Peluso. Por outro lado, os ministros Ricardo Lewandowski e Ayres Brito defenderam uma revisão da lei, alegando que a anistia não teve caráter amplo, 
geral e irrestrito. Segundo estes ministros, certos crimes são, pela sua natureza, absolutamente incompatíveis com qualquer ideia de criminalidade política pura ou por conexão (BRASIL, 2010). Os ministros Dias Toffoli e Joaquim Barbosa não participaram do julgamento. ${ }^{1}$

\subsection{A ADPF 153 à Luz do Direito Internacional dos Direitos Humanos}

Durante o julgamento da ADPF n. 153, argumentos interpretativos que se distanciavam da normativa internacional foram o destaque nos votos dos ministros. Em suas alegações, preponderou a referência a teses e correntes de hermenêutica jurídica avançada. A discussão em torno do que seria uma interpretação do artigo $1^{\circ}, \S 1^{\circ}$, da Lei de Anistia conforme os preceitos da Constituição da República Federativa do Brasil de 1988 teve pouco destaque. Chama a atenção o fato de que a preponderância dos direitos humanos na Constituição de 1988, considerada a mais cidadã na história brasileira, e a implicação de anistia a crimes comuns dentro de um Estado Democrático de Direito, não foram argumentos suficientemente entabulados nas discussões.

Conforme afirmado por Ventura (2010), há necessidade de adequar a jurisprudência do STF à ordem constitucional brasileira, humanista e democrática, quanto ao teor das obrigações internacionais paulatinamente assumidas pelo Brasil, graças às numerosas convenções relativas aos direitos humanos firmadas e incorporadas à ordem jurídica pátria.

Ainda que o julgamento, e principalmente o voto do relator, tenha sido marcado por tais "malabarismos sofísticos" (SILVA FILHO, 2012), este tópico tratará de dois argumentos que se considera os mais notórios: o suposto acordo político que foi a Lei de Anistia e a segurança jurídica diante da perspectiva do Direito Internacional dos Direitos Humanos.

O uso da expressão "acordo político" para caracterizar a Lei n. 6.683/79 aparece em todos os votos das ministras e ministros que se pronunciaram pelo indeferimento da Arguição. Destaca-se aqui o voto do relator:

A inicial ignora o momento talvez mais importante da luta pela redemocratização do país, o da batalha da anistia, autêntica batalha. Toda a gente que conhece nossa História sabe que esse acordo político existiu, resultando no texto da Lei n. 6.683/79 (BRASIL, 2010, p. 21) (grifamos).

Logo, o voto se desdobra a relatar importantes marcos na luta pela Lei de Anistia, como as perseguições dos policiais militares nas passeatas em favor da anistia, os atentados contra as bancas de jornais e as greves de fome de presos políticos durante a votação da lei. Apesar de descrever verdadeiramente os atos que marcaram o movimento nacional e internacional pela anistia dos presos políticos, o relator ignora as circunstâncias da votação do projeto. Ademais, cita uma entrevista com o jurista Dalmo Dallari, que também foi preso político por advogar em favor da resistência ao regime. Na própria entrevista fica claro que o movimento

O ministro Dias Toffoli não participou do julgamento porque estava à frente da Advocacia Geral da União (AGU) à época em que a ação foi ajuizada e chegou a anexar informações ao processo. Já o ministro Joaquim Barbosa estava em licença médica (BRASIL, 2010). 
pela anistia teve de abrir mão de pontos fundamentais durante as discussões em torno da aprovação da lei, dada a composição do Congresso e das forças que ainda governavam o país em 1979 (BRASIL, 2010).

Tal contradição segue durante a relatoria da ADPF. Ora, como acreditar que presos políticos, Igreja, instituições como OAB e tantos outros núcleos de apoio ao movimento pela anistia seriam favoráveis ao resultado final da votação? A lei excluiu parte dos perseguidos políticos, pois os presos que tiveram seu processo em trânsito julgado, não puderam usufruir da anistia. Ainda, o resultado final da lei beneficiou amplamente os violadores de direitos humanos ligados ao governo ditatorial, pois não impôs restrições a estes. A própria ministra Carmen Lúcia, em seu voto na ADPF, reconheceu o caráter restrito da lei e acrescentou que "sequer era o que aquela entidade [OAB], menos ainda a sociedade brasileira, gostaria de ter obtido" (BRASIL, 2010, p. 82).

É necessário pontuar que o projeto de lei, como aprovado, contrariava a luta civil por uma anistia ampla, geral e irrestrita. O que se teve foi uma lei feita para satisfazer os interesses do regime ditatorial que gradualmente estava deixando o poder e que não aceitaria futuras punições pelos crimes cometidos. Em um regime autoritário e armado, em que a qualquer sinal de oposição há risco de prisões arbitrárias ou até mesmo homicídio, não existe acordo político e conciliação.

O famoso "Pacote de Abril" do governo Geisel (1974-1979) demonstra a farsa da suposta abertura gradual e pacífica. Como bem relembra Silva Filho (2012), o Pacote foi uma resposta à eleição de 1974, na qual o Movimento Democrático Brasileiro (MDB), partido da oposição controlada, obteve expressiva votação. Além do terrorismo de Estado continuar forte como no caso do assassinato de Herzog e do operário Manoel Fiel Filho, ${ }^{2}$ Skidmore (1994) discorre sobre as medidas que Geisel utilizou para controlar a oposição no âmbito do Legislativo: por meio do Ato Institucional n. 5 (Al-5), e com a justificativa que o MDB rejeitava a reforma judiciária, em 1o de abril de 1977 Geisel fecha o Congresso, instaura o "Pacote de Abril", e, assim, torna a eleição de governadores e senadores indireta; simplifica o procedimento de emenda constitucional para maioria simples; fixa o número da população, e não dos eleitores registrados para o número de deputados federais e limita o acesso dos candidatos ao rádio e à televisão nos termos da Lei Falcão, ${ }^{3}$ cuja aprovação ocorreu em 1976 (SKIDMORE, 1994).

Nesse contexto, houve a prisão e cassação de mandatos da oposição, tal como de Alencar Furtado, líder do MDB na Câmara, cujo mandato foi cassado e seus direitos políticos privados pelo período de dez anos (SILVA FILHO, 2012). O Projeto de Lei n. 14, que mais tarde tornou-se a Lei 6.683/79, foi produzido pela Presidência da República. Foi um acordo de portas fechadas - nem mesmo a Arena, o partido do regime, fez parte do processo de elaboração

\footnotetext{
2 Operário metalúrgico morto pela ditadura militar. Em janeiro de 1976, foi preso por dois agentes do DOI-Codi, na fábrica, sob a acusação de pertencer ao Partido Comunista Brasileiro (PCB). No dia seguinte à sua prisão, os órgãos de segurança emitiram nota oficial afirmando que Manuel havia se enforcado em sua cela com as próprias meias. De acordo com colegas, porém, quando preso, usava chinelos sem meias. Quando os parentes conseguiram a liberação do corpo para ser enterrado, verificou-se que apresentava sinais evidentes de torturas, principalmente na região da testa, nos pulsos e no pescoço, no entanto o exame necroscópico confirmava a versão oficial do suicídio. Em ação judicial movida pela família, a União foi responsabilizada pela tortura e pelo assassinato (MEMÓRIAS DA DITADURA, 2019).

3 Segundo Skidmore (1994), a Lei Falcão proibia o uso do rádio ou televisão para fins de campanha política, nos quais só poderia aparecer a imagem sem som do candidato (medida extensiva tanto ao partido Arena quanto ao MDB).
} 
(MEYER, 2012). A votação deu-se nesse contexto de oposição sufocada e Congresso controlado. Assim, é mais que evidente que apesar de o movimento em favor da anistia ter sido um clamor da sociedade nacional e internacional, a lei em si, ao contrário do que os ministros do STF continuamente descreveram em seus votos, não foi uma resposta aos anseios da população e muito menos um acordo político. Vale citar a abertura do voto do ministro Lewandowski, que fez oposição ao voto vencedor:

De fato, a Lei de Anistia, longe de ter sido outorgada dentro de um contexto de concessões mútuas e obedecendo a uma espécie de "acordo tácito", celebrado não se sabe bem ao certo por quem, ela em verdade foi editada em meio a um clima de crescente insatisfação popular contra o regime autoritário (BRASIL, 2010, p. 107).

O segundo ponto que merece destaque nos argumentos dos ministros é quanto à (in) segurança jurídica. Um dos principais problemas de a ADPF ter sido julgada mais de 20 anos após a promulgação da lei, são as consequências jurídicas. É válido, no entanto, relembrar que o pedido inicial realizado pela $O A B$ não foi pela revogação da norma e sim pela interpretação conforme os preceitos constitucionais do inciso 1, do artigo 1‥ Logo, caberia ao Supremo delimitar o alcance dessa interpretação.

Durante a exposição, os ministros destacaram aspectos relacionados à prescrição da persecução penal e a insegurança juridical que poderia decorrer de uma reinterpretação acerca da lei de anistia naquele momento (MEYER, 2012). Entre as de caráter civil, a relatoria do ministro Eros Grau (BRASIL, 2010) faz menção às reparações pecuniárias que vítimas e familiares de vítimas do regime de exceção receberam ao longo dos anos por meio da Comissão de Anistia. Tais argumentos demonstram a visão antiquada da Corte em oposição aos costumes do Direito Internacional.

Conforme Ventura, há um velho "paradoxo penal": o costume internacional e os crimes contra a humanidade. É necessário o diálogo entre o Direito Penal e o Direito Internacional dos Direitos Humanos, pois são "instituições e jurisprudências muito diferentes, de interferência e deslocamentos entre espaços nacionais e internacionais com hierarquias imbricadas, formando 'um sistema realmente singular'” (VENTURA, 2010, p. 18).

Em relação às reparações citadas pelo ministro Grau, a ministra Carmem Lúcia (BRASIL, 2010) elucida que a Lei 6.683/79 anistiou apenas crimes políticos, ou seja, dentro do âmbito do Direito Penal. Segundo De Freitas Cruz (2018), a anistia de 1979 seria uma cláusula excludente da tipicidade criminal sui generis, "pois incide sobre a prática criminosa apenas em certos casos concretos" (DE FREITAS CRUZ, 2018, p. 54), e não no sentido universal, como é a anistia disposta no artigo 107, III, do Código Penal Brasileiro. O caráter exclusivamente penal da anistia brasileira é claro quando se sabe que as primeiras reparações pecuniárias, ainda nos anos 90, foram concedidas pelo Ministério do Trabalho àqueles que tivessem perdido vínculo empregatício em virtude de perseguição política. Em 2001, com a criação da Comissão de Anistia, as reparações alcançaram um caráter mais amplo, com indenizações e pensões a vítimas e familiares de vítimas da ditadura (DE STUTZ; ALMEIDA, 2017).

Segundo Osmo (2016), as vítimas das violações da ditatura utilizaram das ações declaratórias e das ações de natureza indenizatória tanto para obter reparação simbólica e financeira quanto para coletar testemunhos em juízo: 
Havia uma preocupação com a preservação das evidências que poderiam se perder, especialmente os testemunhos de pessoas que se acreditavam em risco, ou que de qualquer forma poderiam não estar mais vivas quando houvesse interesse do Estado em ouvi-las (OSMO, 2016, p. 6).

A questão da segurança jurídica e tratados internacionais é levantada no voto do ministro Celso de Mello ao citar a Convenção sobre a Imprescritibilidade dos Crimes de Guerra e dos Crimes Contra a Humanidade que nunca foi ratificada pelo Brasil (BRASIL, 2010). De acordo com o ministro, a norma internacional de que crimes lesa-humanidade são imprescritíveis não poderia ser adotada no ordenamento interno. Com uma breve pesquisa no site do Ministério das Relações Exteriores, contudo, é possível constatar que durante o regime militar havia 17 normas de Direito Internacional dos Direitos Humanos em plena vigência no Brasil. Entre elas, a Declaração Universal dos Direitos do Homem, a Convenção para a Prevenção e a Repressão do Crime de Genocídio e as Convenções de Genebra.

Conforme Ventura (2010), essas normas internacionais, aliadas ao fato de que o Brasil foi um dos 51 Estados fundadores da Organização das Nações Unidas (ONU), demonstram que o país fez parte desde o início do movimento internacional da universalização dos direitos humanos após a Segunda Guerra Mundial. Ademais, todas as convenções antes destacadas expressamente obrigam os Estados a respeitá-las em todas as circunstâncias. A Convenção para a Prevenção e a Repressão do Crime de Genocídio de 1948, por exemplo, já trazia a noção de crime internacional.

Parte dos integrantes do STF sistematicamente ignora os tratados e convenções internacionais de direitos humanos assinados pelo Brasil, que poderiam ter sido usados como fonte de Direito em seus votos. Em seu lugar, todavia, citam tratados dos quais o Estado brasileiro não faz parte, como forma de enfraquecer a internacionalização do Direito interno. Nesse ponto, é importante frisar que o controle de convencionalidade é uma das competências do STF e do poder Judiciário como um todo. Desde o juízo de primeira instância é necessário verificar se as normas de Direito interno (tanto as normas constitucionais como as infraconstitucionais) estão em conformidade com a normativa internacional de direitos humanos, assim como com a interpretação que os organismos internacionais de monitoramento lhes dão (RAMOS, 2009).

Ademais, a Convenção sobre Imprescritibilidade dos Crimes de Guerra e dos Crimes contra a Humanidade foi citada diversas vezes pelos ministros, como demonstração da não obrigatoriedade de cumprimento, pelo fato de o Brasil não ser signatário. Se na Constituição Federal de 1988 não houvesse a proibição da tortura, a ausência da adesão brasileira possibilitaria ao Estado cometer crimes lesa-humanidade? Não há dúvidas que a resposta é negativa quando se entende que a referida convenção faz parte do contexto internacional de direitos humanos e de combate a esses crimes desde o Tribunal de Nuremberg. A convenção apenas deixou explícita uma norma jus cogens do Direito Internacional. Ainda na contramão dos argumentos do julgamento, uma norma jus cogens não se confunde com o costume internacional, pois ela é superior até mesmo a tratados, por ser um minimum legal de asseguramento da ordem mundial (MEYER, 2012). 
Necessário ressaltar que, em 1998, o Brasil reconheceu a jurisdição da Corte IDH por meio do Decreto Legislativo n. 89/98, que o obriga a adotar as decisões da instituição. Ainda assim, os ministros Eros Grau e Celso de Mello, ao se posicionarem pela prevalência do Direito Interno sobre o Direito Internacional, deixaram de lado a tendência mundial de diálogo entre as duas instituições e ignoraram a jurisprudência consolidada da Corte Interamericana de Direitos Humanos (CIDH) sobre as leis de autoanistia e imprescritibilidade de crimes contra a humanidade. No Caso Almonacid Arellano vs. Chile, por exemplo, a decisão da CIDH foi de que o conceito de crimes contra a humanidade remonta ao início do século 20 , na Convenção de Haia sobre as Leis e Costumes de Guerra Terrestre, ou seja, a Convenção sobre Imprescritibilidade tem natureza meramente declaratória.

Em uma tentativa de corroborar a tese de que a Lei 6.683/79 não foi uma lei de autoanistia, o ministro Celso de Mello cita a jurisprudência da Corte IDH. Destaca-se o Caso Barrios Alto vs. Peru, julgado em 2001 pela CIDH, no qual o Estado peruano foi responsabilizado pelo massacre de 15 pessoas e condenado a investigar e punir o crime. Além disso, foi criado o entendimento de que leis de anistia que impeçam a persecução penal de crimes lesa-humanidade são incompatíveis com o Direito Internacional dos Direitos Humanos:

Esta Corte considera que são inadmissíveis as disposições de anistia, as disposições de prescrição e o estabelecimento de excludentes de responsabilidade que pretendam impedir a investigação e punição dos responsáveis por graves violações de direitos humanos, tais como tortura, execuções sumárias, extralegais ou arbitrárias e desaparecimentos forçados, todas elas proibidas por violar direitos inderrogáveis reconhecidos pelo Direito Internacional dos Direitos Humanos (CORTE... 2001, p. 15).

Na contramão do entendimento do ministro Celso de Mello e por sua vez do STF, Meyer afirma que negar que a Lei de Anistia brasileira foi uma autoanistia, caracterizando-a como uma "anistia de mão dupla", apenas retoma os mesmos problemas apresentados pela CIDH: "o descumprimento efetivo das garantias estatuídas na Convenção Americana de Direitos Humanos e, consequentemente, violação da normativa internacional de proteção dos direitos humanos" (MEYER, 2012, p. 181).

Por fim, cabe a reflexão: a omissão proposital do poder Judiciário em prol de uma suposta reconciliação nacional é válida em casos de crimes contra a humanidade? Conforme mencionado, o Direito Internacional dos Direitos Humanos não permite que Estados utilizem o Direito Interno como justificativa de inadimplemento com as suas obrigações internacionais. Os direitos humanos, além de um recurso de proteção, buscam também a investigação e punição daqueles que o violam. Além disso, a ADPF n. 153 demonstra a omissão não apenas perante o Direito Internacional, mas contra preceitos constitucionais da Constituição Federal de 1988.

O julgamento da ADPF n. 153, além de perpetuar o entendimento ultrapassado da não persecução penal de agentes do regime de exceção, fortaleceu decisões de arquivamento de inquéritos que buscavam a investigação e a verdade. Além disso, tem causado confusão acerca de sua abrangência, na medida em que juízes têm negado indenizações que possuem caráter civil (MEYER, 2012). 
O STF precisa adequar a jurisprudência interna à jurisprudência internacional, reconhecendo a Convenção Interamericana de Direitos Humanos como fonte de Direito e invalidando a Lei de (auto)Anistia, que nunca deveria ter sido recepcionada pela Constituição de 1988, na medida em que esta, em seu artigo 40, inciso II, afirma reger suas relações internacionais pela prevalência dos direitos humanos.

\section{CASO HERZOG VS. BRASIL}

Para que se possa admitir uma petição diante do Sistema Interamericano de Direitos Humanos é necessário o cumprimento de alguns requisitos de admissibilidade constantes no Pacto de San José da Costa Rica: o esgotamento dos recursos locais, ausência do decurso do prazo de seis meses para a representação, ausência de litispendência internacional e ausência de coisa julgada internacional. De acordo com a sentença da $\mathrm{CIDH}$, a família e as organizações que recorreram à Comissão Interamericana de Direitos Humanos (CIDH) no Caso Herzog cumpriram os requisitos.

O processo no âmbito internacional durou cerca de nove anos, como será descrito mais adiante, no entanto no Brasil iniciou-se ainda em 1975, ano em que Vladimir Herzog foi assassinado. Diante da comoção generalizada da população e da imprensa, o general comandante do II Exército deu abertura à investigação da morte com o Inquérito Policial Militar n. 1173-75, que apenas repetiu a versão de suicídio por enforcamento.

Assim, em abril de 1976, a família instaurou a Ação Declaratória n. 136-76 perante a Justiça Federal do Estado de São Paulo. Tal ação foi muito importante, pois durante o trâmite do processo novos fatos vieram à tona. Na audiência de instrução, em julho de 1978, Shibata, um dos médicos que assinaram o laudo em que constava que a morte de Herzog fora por suicídio, admitiu que não fez a autópsia nem teve contato com o corpo da vítima (BRASIL, 2007; CORTE..., 2018).

O juiz de Primeira Instância proferiu sentença em favor da família de Herzog, concluindo que Vladimir foi morto pelos agentes da repressão e rechaçando a primeira versão de suicídio. A União interpôs Recurso de Apelação e após nova decisão contrária, recurso de Embargos Infringentes. A decisão definitiva veio apenas em setembro de 1995. Apesar de reconhecido o abuso de autoridade, tortura, ilegalidade da prisão, fraude no atestado de óbito e nos depoimentos, durante o trâmite da ação, a Lei n. 6.683/79 foi sancionada. Logo, não houve investigação para a responsabilização individual do crime (CORTE..., 2018).

Outras tentativas foram feitas ao longo dos anos, todas sem sucesso. Como consequência do esgotamento dos recursos internos, em 2009 a família de Vladimir, em conjunto com diversas organizações brasileiras de proteção aos direitos humanos, recorreu à CIDH. Em abril de 2016 o caso foi submetido à CIDH e, finalmente, em março de 2018 a sentença foi publicada. A CIDH decidiu que o Estado brasileiro deliberadamente foi omisso com a família Herzog, impedindo o direito à informação, ferindo o direito às garantias processuais, à proteção processual e à integridade pessoal.

Publicada em 15 de março de 2018, a sentença do Caso Herzog da CIDH é a segunda decisão no organismo internacional cujo recorte histórico é o período ditatorial militar brasileiro (1964-1985). A primeira foi o Caso Gomes Lund, também chamado de Guerrilha do Araguaia. 
Para entender as consequências que a decisão teoricamente deveria ter no ordenamento jurídico brasileiro, é necessário uma sucinta explicação sobre a competência da $\mathrm{CIDH}$ e o os passos que levaram a família de Herzog a buscar a jurisdição internacional.

\subsection{O Sistema Interamericano de Direitos Humanos e o Direito Interno}

A Convenção Americana de Direitos Humanos ou Pacto de San José da Costa Rica, foi promulgada em 22 de novembro de 1969 em São José da Costa Rica. O governo brasileiro aderiu à Convenção ao depositar a carta em 25 de setembro de 1992 e a ratificou internamente em 6 de novembro do mesmo ano, por meio do Decreto n. 678. A primeira controvérsia sobre o tema é seu status na legislação interna: até 2004, antes da Emenda Constitucional (EC) n. 45/2004, tratados de direitos internacionais tinham aplicação imediata, de acordo com o artigo 5o da Constituição Federal de 1988:

Art. 5o Todos são iguais perante a lei, sem distinção de qualquer natureza, garantindo-se aos brasileiros e aos estrangeiros residentes no país a inviolabilidade do direito à vida, à liberdade, à igualdade, à segurança e à propriedade, nos termos seguintes:

$\S 1$ 을 normas definidoras dos direitos e garantias fundamentais têm aplicação imediata.

$\S 2$ O Os direitos e garantias expressos nesta Constituição não excluem outros decorrentes do regime e dos princípios por ela adotados, ou dos tratados internacionais em que a República Federativa do Brasil seja parte (BRASIL, 1988) (grifamos).

No entanto, a EC n. 45/2004 inaugurou a necessidade de um rito para a incorporação dos tratados de direitos humanos ao ordenamento pátrio. A partir daí, então, passou a ser necessária a votação em cada Casa do Congresso Nacional, em dois turnos, por três quintos dos votos dos respectivos membros, para que esses documentos tenham o status de EC no Direito Interno. A controvérsia, todavia, ainda não havia sido pacificada e foi necessário um posicionamento do STF, que o fez em 2008, no julgamento do RE n. 466.343. Neste, o STF decidiu que tratados e convenções de direitos humanos que não passaram pelo rito incorporado na EC n. 45/2004 têm caráter de norma supralegal, paralisando a eficácia de normas infraconstitucionais em sentido contrário.

A Convenção Americana de Direitos Humanos estabelece dois organismos de monitoramento de direitos humanos: a Comissão Interamericana de Direitos Humanos (CIDH) e a Corte Interamericana de Direitos Humanos (IDH). Ao contrário do Sistema Europeu de Proteção aos Direitos Humanos, no Sistema Interamericano a reclamação direta individual perante a CIDH não é possível. Para isso é necessário que a parte reclamante se dirija primeiramente à CIDH, que tem como função principal "zelar, pelo prisma jurídico, pela promoção de direitos humanos" (RAMOS, 2017, p. 104). Assim como no Caso Herzog, após a apresentação da petição individual alegando violações de direitos humanos, há o início de um procedimento de apuração, estabelecendo-se o contraditório, a ampla defesa do Estado e tendo o esgotamento dos recursos internos como requisito de admissibilidade para a continuidade do processo (RAMOS, 2017). 
A CIDH tem caráter conciliatório. Após o exame do procedimento e apuração dos fatos, busca-se uma solução amistosa entre as partes - o que não ocorreu no Caso Herzog. Em decorrência da omissão do Estado-parte, é elaborado um relatório com recomendações e estipula-se o prazo de três meses para o cumprimento dessas recomendações. Caso não haja seu cumprimento, a Comissão encaminha a denúncia para a apreciação da $\mathrm{CIDH}$.

Todos esses passos foram realizados pela família de Herzog. A denúncia à CIDH foi submetida em 22 de abril de 2016. Segundo Fix-Zamudio, a CIDH tem natureza consultiva, na medida em que interpreta as disposições da Convenção Americana de Direitos Humanos, e também tem caráter jurisdicional, pois soluciona as controvérsias acerca da interpretação ou aplicação da própria Convenção (FIX-ZAMUDIO, 1988, p. 45-46). Quanto ao caráter contencioso, o Brasil reconheceu a jurisdição da CIDH. Por conseguinte, é seu dever como Estado-parte o cumprimento da Convenção Americana de Direitos Humanos e também da jurisprudência e sentenças nas quais for condenado, pois possuem natureza vinculante. A força vinculante está assegurada no artigo 27 da Convenção de Viena, da qual o Brasil também é signatário.

\subsection{Direitos Violados no Caso Herzog}

Ao contrário do que foi noticiado em manchetes de grandes veículos de comunicação brasileiros, a CIDH não condenou o Brasil pelo assassinato de Vladimir Herzog - o Estado brasileiro já havia reconhecido sua responsabilidade pela prisão ilegal, tortura e morte do jornalista, no entanto omitiu-se de investigar e responsabilizar os agentes públicos em virtude da Lei de Anistia. As violações do Estado no caso foram: privar Herzog, sua esposa Clarice e seus filhos, Ivo e André, do direito às garantias judiciais e à proteção judicial; do direito à verdade; e violar a dignidade pessoal das vítimas (CORTE..., 2018).

A análise dos direitos na decisão foi feita da seguinte maneira: primeiramente foram expostas as alegações das partes e da $\mathrm{CIDH}$, demonstrando a retórica entre os argumentos utilizados entre os requerentes e o Estado. Após, foram feitas as considerações da CIDH, que constitui a maior parte da análise. As considerações dedicam-se a esclarecer conceitos e demonstrar o entendimento da Corte sobre as violações ao longo dos anos por meio da sua jurisprudência.

A primeira violação apresentada pelos requerentes e a $\mathrm{CIDH}$ foi o direito às garantias judiciais e à proteção judicial. A CIDH considerou que a morte de Herzog constituiu uma grave violação aos direitos humanos, já os requerentes entenderam que o assassinato foi um crime contra a humanidade. As consequências dos dois é a mesma: seria criada a "obrigação do Estado de investigar, julgar e punir os responsáveis pelos fatos, sem recorrer a obstáculos processuais que poderiam chegar a protegê-los da ação da justiça" (CORTE..., 2018).

Dentro da sua defesa, o Estado brasileiro informou que normas jus cogens ou de graves violações de direitos humanos no âmbito internacional não estão acima de questões processuais (prescrição, coisa julgada e irretroatividade da lei penal mais severa) e que não poderia ser responsabilizado por denegar as garantias processuais nesse caso. Para o Estado, não é possível fundamentar a imprescritibilidade penal no costume internacional, porque isso contrariaria o princípio de legalidade consagrado no artigo $9^{\circ}$ da Convenção Americana de Direitos Humanos (CORTE..., 2018). 
De imediato, a Corte entendeu que o Caso Herzog representa uma grave violação de direitos humanos e, então, passou a analisar se é um crime contra a humanidade. Como afirmado anteriormente, a noção de crimes contra a humanidade é anterior à Convenção sobre Imprescritibilidade e, de acordo com a $\mathrm{CIDH}$, trata-se de crimes de Estado cometidos tipicamente por agentes públicos, que fazem parte de uma estratégia ou política manifesta contra uma população ou grupo de pessoas. Os crimes podem ser assassinato, tortura, estupro ou qualquer outro ato repudiável contra civil praticado de forma sistemática ou generalizada. A CIDH informou, ainda, que durante seus 40 anos de funcionamento, apenas quatro casos foram classificados como crimes contra a humanidade, dada a excepcionalidade e gravidade dessa qualificação (CORTE..., 2018).

É notável o caráter sistemático e organizado da conduta do Estado brasileiro durante o regime autoritário. Entre diversos elementos elencados pela $\mathrm{CIDH}$, chama a atenção a difusão da Doutrina de Segurança Nacional, que criou diversas instituições que tinham como objetivo obter o máximo de informação dos considerados "subversivos" (PEREIRA, 2010). A Diretriz Presidencial de Segurança Interna no plano do poder Executivo deu origem aos Centros de Informação do Exército (CIE), da Marinha e da Aeronáutica, Zonas de Defesa Interna, ConseIhos e Centros de Operações de Defesa Interna e Destacamentos de Operações de Informação (os temidos DOI-Codi) (CORTE..., 2018). A CIDH indicou que o Manual do CIE estabelecia que o preso não poderia apresentar sinais de coação para suas confissões. Segundo Pereira (2010), isso revela o alto nível de cooperação entre o poder Judiciário e as Forças Armadas, de maneira que "a lei era manipulada, distorcida e usada de forma abusiva - ou mantida inalterada - sob o autoritarismo" (PEREIRA, 2010, p. 38).

Além de constatado o caráter organizado e sistemático, a perseguição contra civis não foi feita apenas como forma de obtenção de informações, mas também para o desmantelamento da oposição, armada ou não. Os interrogatórios e torturas eram, inclusive, acompanhados por profissionais da área da saúde:

[...] a tortura passou a ser sistematicamente usada pelo Estado brasileiro desde o golpe de 1964, seja como método de obtenção de informações ou confissões (técnica de interrogatório), seja como forma de disseminar o medo (estratégia de intimidação) (CORTE..., 2018, p. 60).

A CIDH, portanto, concluiu que a detenção ilegal, tortura e assassinato contra Herzog não foi um caso isolado durante a ditadura militar. Pelo contrário, ele fez parte de um plano sistemático e generalizado de um Estado extremamente organizado contra a população civil opositora, preenchendo os requisitos para considerá-lo o quinto caso de crime contra a humanidade julgado na CIDH. Além disso, relembrou todos os processos do Caso Herzog no âmbito interno, reiterando que a falta de tipificação no ordenamento não isenta o Estado de investigar e punir seus agentes. Na sentença, a CIDH afirmou também que o crime contra a humanidade não é um crime em si mesmo, mas sim um conjunto de ações, entre as quais o assassinato e a tortura (que dentro do Código Penal Brasileiro já possuíam equivalentes como a lesão corporal e o homicídio qualificado).

Outrossim, a CIDH relembrou que o Brasil reconheceu a responsabilidade do assassinato de Herzog na Ação Declaratória n. 136-76, contudo, no contexto de crimes cometidos durante a ditadura, o STF decidiu que a Lei de Anistia é constitucional, não cumprindo com 
as suas obrigações internacionais. Logo, a supressão do controle de convencionalidade fez com que as violações fossem tanto pela falta de investigação e punição dos responsáveis pelo assassinato de Herzog, quanto pelo fato de o Brasil descumprir a obrigação de adequar seu Direito Interno à Convenção. Ao aplicar a Lei de Anistia neste caso e em outros, o Brasil descumpriu este dever.

Quanto ao direito à verdade, a primeira violação foi a versão falsa de suicídio, sustentada por anos pelo Estado brasileiro. Mesmo após a vitória na Ação Declaratória n. 136-76, a causa mortis no atestado de óbito de Herzog só foi modificado em 2013 (SANTIAGO, 2013). De acordo com os requerentes, tal situação causou grande sofrimento à família. A segunda violação, além de atingir diretamente Herzog e sua família, também repercute e gera grave impacto à população brasileira como um todo: o ocultamento dos documentos oficiais militares. Nem mesmo durante a transição democrática ou durante a permanência da Comissão Nacional da Verdade (CNV), entre os anos de 2012 e 2014, tais documentos foram abertos. A justificativa para tal omissão foi de "não abrir feridas" (GONZALES, 2019). Tal ocultamento, todavia, configura um obstáculo para a verdade histórica e para o estabelecimento da verdade como meio de justiça e informação.

O Estado brasileiro afirmou que no Caso Herzog, a Ação Declaratória já demonstrava o posicionamento oficial quanto ao assassinato de Vladimir e que as circunstâncias da sua morte já haviam sido esclarecidas, tanto na ação quanto na Comissão Especial de Mortos e Desaparecidos Políticos (CEMDP) e na CNV. Quanto aos documentos oficiais, porém, declarou que o Estado, com base no artigo 20 da Convenção Americana de Direitos Humanos, tem o direito de exercer políticas públicas, administrativas e legislativas com a discricionariedade que lhe é devida (CORTE..., 2018).

Em suas observações, a CIDH afirmou que reconhece os trabalhos da CEMDP e da CNV como fundamentais para a reparação das vítimas da ditadura e do caso concreto, entretanto foram necessários 15 anos para que houvesse a retificação do atestado de óbito de Vladimir. Ademais, o acesso à informação e aos arquivos públicos partem do princípio da boa-fé no acesso à informação. Assim, o Estado não deve eximir-se de sua obrigação, devendo destinar recursos para reconstruir informações que supostamente foram destruídas. Caso haja recusa para a sua prestação, que ela seja motivada e fundamentada, pois o risco de esse ato significar a violação de direitos fundamentais é alto (CORTE..., 2018).

Por fim, a violação do direito à integridade pessoal. A CIDH e os requerentes destacaram o dano psíquico e moral dos familiares de Vladimir Herzog: Zora, mãe de Vladimir, que faleceu em novembro de 2006, a esposa Clarice e os filhos, André e Ivo. O dano se deu pelo assassinato sem a investigação e punição dos agentes responsáveis, pela versão falsa de sua morte e pelo terror e intimidação sofridos pela família no contexto das violações. Clarice informou que, inclusive, foi ameaçada de morte em reiteradas ocasiões (CORTE..., 2018). O Estado reconheceu que a sua conduta impôs aos familiares dor intensa, todavia empregou "múltiplos esforços com o propósito de reparar os danos sofridos" (CORTE..., 2018, p. 88). A família de Herzog foi uma das beneficiárias da reparação pecuniária no valor de $R \$ 100.000,00$, dada pelo Estado às vítimas do regime ditatorial no levantamento feito pela Comissão de Anistia (CORTE..., 2018; DE STUTZ; ALMEIDA, 2017). 
A CIDH julgou-se incompetente para decidir sobre a violação ligada diretamente à tortura e assassinato em razão da competência temporal da instituição, todavia, em consequência da falta de investigação, julgamento, punição dos algozes e do impedimento ao acesso à verdade, restou como violado o direito à integridade psíquica e moral dos familiares de Vladimir (CORTE..., 2018).

Cabe aqui mencionar a decisão final da CIDH sobre o caso. O Estado brasileiro foi condenado a investigar, identificar, processar e, caso seja pertinente, punir os responsáveis pela tortura e morte de Vladimir, considerando o caráter imprescritivel de crime contra a humanidade. Assim, fazendo uso do controle de convencionalidade, adotar as medidas necessárias para que, no Direito Interno, se reconheça a imprescritibilidade dos crimes lesa-humanidade e internacionais. Quanto às reparações, como forma de não repetição, o Estado brasileiro deverá realizar um ato público de reconhecimento de responsabilidade internacional pelos fatos, em desagravo à memória de Herzog, à falta de investigação, julgamento e punição dos responsáveis por sua tortura e morte. Deverá ainda ser feito o pagamento dos montantes estabelecidos pelos danos materiais, imateriais, reembolso de custas e gastos nos termos da sentença (CORTE..., 2018).

\section{JUSTIÇA DE TRANSIÇÃO}

De acordo com o Relatório S/2004/616 do Conselho de Segurança da Organização das Nações Unidas, Justiça de Transição pode ser entendida como o conjunto de medidas e mecanismos associados à tentativa de uma sociedade lidar com um legado de abusos em larga escala no passado, a fim de assegurar que os responsáveis prestem contas de seus atos, que seja feita justiça e se conquiste a reconciliação. Tais mecanismos podem ser judiciais e/ou extrajudiciais, com diferentes níveis de envolvimento internacional (ou nenhum), bem como abarcar o juízo de processos individuais, reparações, busca da verdade, reforma institucional, investigação de antecedentes, a destituição de um cargo ou a combinação de todos esses procedimentos (SECURITY COUNCIL OF UNITED NATIONS, 2004). Não há hierarquia ou necessária ordem de cumprimento desses mecanismos e cada país dá o enfoque que julgar necessário no processo transicional.

Diante desse conceito é possível delimitar os elementos centrais para o processo transicional: memória e verdade, reparação, justiça ou persecução dos perpetradores e reforma institucional. Todos eles são interligados e tangenciam-se. A memória pode ser resgatada de diversas formas, como em construção de memoriais, museus, datas comemorativas, criação de comissões da verdade, homenagem às vítimas em obras públicas, apoio financeiro para projetos independentes que buscam tal recuperação, como documentários, filmes e livros. 0 importante é a difusão de uma memória coletiva para que a sociedade entenda as atrocidades cometidas na ditadura, de modo que não sejam repetidas.

A reforma de instituições tem um importante papel em governos que buscam o processo de ruptura com o antigo regime autoritário e visam à redemocratização. É necessário que instituições e agentes que antes estiveram ligados a violações de direitos humanos ou que utilizaram de sua influência para perpetuar ou legitimar atos abusivos, não se mantenham agindo em nome do Estado. Para tanto, os expurgos do serviço público ou dissolução de instituições são soluções possíveis. 
A reparação também assume formas distintas. Ela pode ocorrer por meio de ajuda material, como pensões, indenizações, bolsas de estudos, de assistência psicológica ou de medidas simbólicas, como na construção de memoriais para as vítimas (VAN ZYL, 2011). Finalmente, a Justiça é o eixo que busca a persecução judicial, administrativa, civil e penal de violadores de direitos humanos. Segundo De Stutz e Almeida (2017), a persecução judicial tem como fim acalmar os traumas do passado e curar feridas, não como forma de vingança, mas com o objetivo de reconciliação. No próximo item será demonstrado como o Brasil tem tratado os diferentes eixos da Justiça de Transição.

\subsection{Justiça de Transição à Brasileira}

Entre os pilares demonstrados, a reparação foi o eixo em que o Brasil baseou o seu processo de transição e redemocratização no sentido mais estrito. Assim, não se procurava o estabelecimento da verdade ou a justiça penal como parte da reparação, mas sim oferecer benefícios diretamente às vítimas (DE GREIFF, 2011). A Comissão de Anistia, criada pela Lei 10.559/02 e vinculada ao Ministério da Justiça, foi o principal meio pelo qual as vítimas puderam ser reparadas economicamente. Por meio dela é possível dois tipos de reparação econômica: a de prestação única limitada ao teto de $\mathrm{R} \$ 100.000,00^{4}$ e a reparação de prestação mensal, permanente e continuada, que é concedida nos casos de perda laboral (DE STUTZ; ALMEIDA, 2017).

Até 2018, nas sessões da Comissão de Anistia, após a leitura do processo e a decisão pela anistia do perseguido político, havia o pedido oficial de desculpas do Estado brasileiro ao anistiado ou aos seus familiares. O pedido de desculpas era uma verdadeira garantia de não repetição tanto para a vítima quanto para toda a sociedade brasileira. Constituía um dos momentos mais importantes do ato (DE STUTZ; ALMEIDA, 2017). Durante o governo do presidente Michel Temer, no entanto, com a indicação de novos integrantes ao Conselho da Comissão de Anistia, o "ritual do perdão" foi suspenso, um dos atos mais significativos de reparação simbólica no Brasil (ÉBOLI, 2019).

Quanto aos outros eixos, pouco se trabalhou Justiça de Transição no Brasil. As reformas institucionais foram tímidas e pode-se afirmar que a promulgação da Constituição Federal de 1988 significou o grande, e talvez único, marco nessa direção. Quanto ao eixo Justiça, a situação piora, em razão da Lei de Anistia, que não permitiu ao menos a investigação de casos envolvendo os agentes públicos perpetradores. No contexto das ditaduras latino-americanas do século passado, o Brasil é o único país do Cone Sul que manteve a anistia sem exceções e, assim, não condenou nenhum violador de direitos humanos (BRASIL, 2007).

O Brasil é o único país do Cone Sul que não trilhou procedimentos semelhantes para examinar as violações de direitos humanos ocorridas em seu período ditatorial, mesmo tendo oficializado, com a Lei no 9.140/95, o reconhecimento da responsabilidade do Estado pelas mortes e pelos desaparecimentos denunciados (BRASIL, 2007, p. 21).

$\overline{4}$ A família de Herzog recebeu tal indenização, como mencionado anteriormente. 
Por fim, o pilar da memória e verdade. Ainda nos anos 90, durante o governo de Fernando Henrique Cardoso, houve a instalação da Comissão sobre Mortos e Desaparecidos Políticos que, além da investigação e indenização aos familiares das vítimas, resultou na criação do documento "Direito à memória e à verdade". Já o relatório "Brasil, Nunca Mais", de 1985, foi um dos mais importantes documentos de acesso à informação e teve uma produção independente. Foi organizado pela Arquidiocese de São Paulo a partir de documentos retirados de autos de processos que tramitavam perante a Justiça Militar.

Em razão da condenação no Caso Gomes Lund perante a CIDH, o Brasil criou a CNV, por meio da Lei n. 12.528, de 18 de novembro de 2011. Segundo o artigo $4^{\circ}$ da lei, para exercer suas funções a CNV poderia receber testemunhos, informações, dados e documentos que Ihe fossem encaminhados voluntariamente, assegurada a não identificação do detentor ou depoente, quando solicitada; requisitar informações, dados e documentos de órgãos e entidades do poder público, ainda que classificados em qualquer grau de sigilo, e promover parcerias com órgãos e entidades, públicos ou privados, nacionais ou internacionais, para o intercâmbio de informações, dados e documentos.

A CNV teve a duração de apenas dois anos e tinha como objetivo esclarecer os fatos e as circunstâncias dos casos de graves violações de direitos humanos, identificando as estruturas, locais e instituições relacionadas à prática de tais violações. Além disso, caso fosse pertinente, poderia encaminhar aos órgãos públicos competentes toda informação obtida para que fossem localizados e identificados corpos e restos mortais de desaparecidos políticos (BRASIL, 2011).

\subsection{Onde Está o Controle de Convencionalidade?}

Os pilares da Justiça de Transição transparecem na condenação brasileira no Caso Herzog. A CIDH determinou que o Estado promova a investigação, responsabilização e punição dos algozes de Vladimir. Em razão de a Corte ter conhecimento de que a ADPF n. 153 configura um obstáculo para o cumprimento de sua decisão, a sentença dispôs também pela necessidade do uso do controle de convencionalidade no Direito Interno. Esse primeiro ponto da sentença da $\mathrm{CIDH}$ demonstra a importância do eixo Justiça.

Como afirmado anteriormente, a Justiça vai além da punição dos violadores. A ideia de uma Justiça retributiva não pode ocupar todo o espaço reservado à Justiça. Deve-se pensar no conceito de uma Justiça restaurativa, que se propõe reconciliar as vítimas e o Estado, restaurar a confiança e posicionar-se contra as violações praticadas (BUENO, 2015).

Para Méndez, um Estado Democrático de Direito é obrigado a realizar uma série de ações como resposta a crimes contra a humanidade, quais sejam:

investigar, processar e punir perpetradores; revelar para vítimas, familiares e sociedade tudo o que pode ser confiavelmente estabelecido a respeito dos fatos ocorridos; oferecer às vítimas reparação adequada e afastar reconhecidos perpetradores de órgãos policiais e de outras posições de autoridade (MENDÉZ, 2011, p. 200). 
Em um governo recém-democrático como foi o caso brasileiro nos anos 90, é escusável a não persecução pela fragilidade do novo regime. Ademais, a situação brasileira se agrava quando é relembrado que o governo não fez reformas institucionais, todavia diversos países que passaram por ditaduras na América Latina revisaram suas leis de anistia, adequando-se à jurisprudência internacional.

Como exemplo, o Peru tem grande importância no contexto de invalidações de leis de anistia por ter sido o país que deu início à jurisprudência da CIDH no Caso Barrios Alto vs. Peru. Após os dez anos de governo autoritário de Fujimori, o Peru voltou a dialogar com o Sistema Interamericano de Direitos Humanos. Por meio de uma resolução do Ministério Público peruano, a sentença da CIDH passou a ser executada. Em 2005, a Corte afirmou que o Estado cumpriu com as suas obrigações, declarando a ineficácia de suas leis de autoanistia (CANTON, 2011).

Na mesma direção, também em 2005, a Suprema Corte da Argentina entendeu que o Estado argentino, desde a Constituição de 1994, assumiu o dever de adequação de seu Direito Interno à ordem jurídica interamericana. Por conseguinte, fazendo uso do controle de convencionalidade, os ministros concluíram que a Lei de Ponto Final e a Lei de Desobediência Devida $^{5}$ eram inconstitucionais por serem contra a Convenção Americana de Direitos Humanos e a decisão da CIDH no caso peruano (LUCAS; OLIVEIRA, 2016).

Ademais, outros países derrubaram ou abriram exceções nas suas leis de auto- anistia ao longo dos anos. O Chile considerou que o crime de desaparecimento forçado é um crime permanente. Na Guatemala, crimes contra humanidade não podem ser anistiados (HOLLANDA et al., 2010). Em 2011, o parlamento do Uruguai criou lei que não permite prescrição dos crimes cometidos na ditadura, no entanto em 2016 a Corte Suprema Uruguaia vetou alguns dispositivos da lei, mas confirmou a anulação da Lei de Caducidade. Ainda em 2016, El Salvador também derrubou sua lei de anistia.

Todos esses exemplos de reinterpretações demonstram a tendência sul-americana de reconciliação com o passado. Para que haja tais decisões é inegável o peso político impulsionado pela sociedade civil. Eis a importância da condenação no Caso Herzog sobre a violação do direito à informação, direito este que se adéqua ao eixo da memória e verdade: uma sociedade que tem conhecimento e que não esquece as atrocidades cometidas no passado tende a não repeti-las, no entanto o caso brasileiro foi de um esquecimento imposto aliado a uma falsa transição pacífica sem rupturas ou reformas, que consequentemente resultou na interpretação dos ministros do STF na ADPF n. 153.

A mudança na interpretação do STF é fundamental não só para o cumprimento da sentença da CIDH, mas também para que a instituição cumpra a sua função de importante guardiã da Constituição. Afinal, tratados de direitos humanos estão no bloco constitucional ou de supralegalidade.

\footnotetext{
5 "A edição das referidas leis marcou o encerramento dos julgamentos penais dos crimes ocorridos durante a ditadura militar na Argentina" (LUCAS; OLIVEIRA, 2016, p. 920).
} 
O ministro Cezar Peluso, no seu voto na ADPF n. 153, afirmou que a Lei 6.683/79 não era um caso de "autoanistia censurada pelos tribunais internacionais" (BRASIL, 2010, p. 210). Um ano depois, contudo, na condenação do Caso Gomes Lund, que em 2018 foi ratificada no Caso Herzog, a CIDH posicionou-se de forma contrária ao entendimento do ministro Peluso:

As disposições da Lei de Anistia brasileira que impedem a investigação e sanção de graves violações de direitos humanos são incompatíveis com a Convenção Americana, carecem de efeitos jurídicos e não podem seguir representando um obstáculo para a investigação dos fatos do presente caso, nem para a identificação e punição dos responsáveis, e tampouco podem ter igual ou semelhante impacto a respeito de outros casos de graves violações de direitos humanos consagrados na Convenção Americana ocorridos no Brasil (CORTE..., 2010, p. 113).

Em geral, é muito difícil encontrar repercussão no STF das decisões internacionais de direitos humanos oriundas de órgãos dos quais Brasil reconhece a jurisdição (RAMOS, 2009). É necessário que a instituição reconheça as mudanças no cenário internacional e compatibilize sua jurisprudência com a hermenêutica do Direito Internacional dos Direitos Humanos. Como bem lembra Meyer (2012), o STF não está vinculado a suas próprias decisões e o Caso Herzog é uma nova oportunidade de a instituição demonstrar o seu compromisso com o Estado Democrático de Direito e os direitos humanos.

\section{CONSIDERAÇÕES FINAIS}

A hipótese estabelecida para o presente trabalho foi confirmada: o STF ignora o debate contemporâneo sobre a internacionalização do Direito Interno, não assumindo seu compromisso perante órgãos internacionais e decidindo deliberadamente contra a jurisprudência internacional. Na ADPF n. 153, além da falta do uso do controle de convencionalidade, empregou o Direito Comparado de forma equivocada. Além disso, apresentou uma visão ultrapassada no que tange à hermenêutica do Direito Internacional dos Direitos Humanos (VENTURA, 2010).

A arguição proposta pelo Conselho Federal da $O A B$ reacendeu o debate sobre a Justiça de Transição no país. A sentença da CIDH no Caso Herzog demonstra a importância da Justiça de Transição, não só para os familiares de vítimas da ditadura, mas para toda a sociedade brasileira. É possível partir de uma das teses de Ost (1999), de que a função principal do jurídico é contribuir para a instituição do social. Isso significa que o Direito é um discurso performativo, um tecido de ficções operatórias que exprimem o sentido e o valor da vida em sociedade (OST, 1999).

Então, no julgamento do caso Herzog, o STF perdeu uma importante oportunidade de contribuir para a necessária revisão de fatos de nossa história coletiva que deixaram marcas profundas na sociedade, sobretudo nas pessoas e famílias diretamente atingidas pela repressão ditatorial. Perdeu a oportunidade de contribuir para que tais fatos sejam revisitados, não para abrir feridas, mas justamente para auxiliar em seu processo de cura, que necessariamente envolve a verdade e o perdão. É possível tirar partido dos ensinamentos do passado e assumir a responsabilidade por seus erros, de maneira a orientar o futuro (OST, 1999). Em todos os aspectos mencionados, portanto, equivocou-se o STF em sua decisão. 
Quanto ao Brasil, tendo em vista que a Constituição Federal de 1988, em grande medida, não representou uma ruptura completa em relação ao antigo regime, como já afirmado, as consequências da desinformação e do esquecimento imposto são assustadoras. Em seu voto na ADPF n. 153, o ministro Cezar Peluso afirmou que "uma sociedade que queira lutar contra os inimigos com as mesmas armas, os mesmos instrumentos, os mesmos sentimentos, está condenada a um fracasso histórico" (BRASIL, 2010, p. 214), fazendo assim, uma comparação esdrúxula entre persecução penal de violadores de direitos humanos e os métodos utilizados pelo governo militar. Ora, a sentença do Caso Herzog relembra alguns dos métodos: choque elétrico, pau-de-arara, sufocamento, estupro, mutilação, espancamento e ameaça (CORTE..., 2018).

O objetivo de casos como o de Herzog, Gomes Lund e tantos outros que tramitam na Justiça brasileira sem ainda terem alcançado o Sistema Interamericano de Direitos Humanos não parece ser a vingança.

A investigação e a responsabilização penal, com direito à defesa e ao contraditório, entre outros pressupostos processuais que garantem o devido processo legal, em nada se assemelham aos "métodos utilizados pelo inimigo". Pelo contrário, um Estado que condena violadores de direitos humanos demonstra o seu compromisso com a dignidade da pessoa humana, não coincidentemente, um dos fundamentos da República Federativa do Brasil.

Decorridos oito anos do julgamento da ADPF n. 153, a composição do STF mudou, o Brasil foi condenado em duas ocasiões por violações de direitos humanos resultantes da ditadura militar e, sem previsão de julgamento, os Embargos de Declaração da ADPF n. 153 estão parados. De 2010 para 2018, o Brasil tem passado por uma onda de revisionismo histórico que torna imperativo a retomada da discussão sobre os horrores do regime autoritário. Nas eleições que precederam a escrita deste artigo, o vencedor da disputa da Presidência, Jair Messias Bolsonaro, posicionou-se a favor da ditadura militar, contra a investigação e procura de restos mortais dos assassinados na guerrilha do Araguaia, homenageou Brilhante Ustra, um dos torturadores mais conhecidos do regime de 1964, e parece flertar com a censura (BOLSONARO..., 2016).

A onda de revisionismo e a desinformação generalizada são consequências de um Estado que não se preocupou em fazer as pazes com o passado. Nesse sentido, este artigo teve como objetivo retomar o debate acerca da necessidade da instituição de medidas de Justiça de Transição. Ainda que tardiamente, no contexto político vivido atualmente no Brasil, é imprescindível que o Estado brasileiro, e dentro do recorte escolhido, o STF, cumpra a sentença do Caso Herzog. Assim, demonstrará para a população brasileira e a sociedade internacional que é um país que reconhece a sua responsabilidade e se alinha ante a jurisprudência do Direito Internacional dos Direitos Humanos.

\section{REFERÊNCIAS}

BOLSONARO DIZ NO CONSELHO DE ÉTICA QUE CORONEL USTRA É “HERÓI BRASILEIRO”. G1 [on-line]. 2016. Disponível em: http://g1.globo.com/politica/noticia/2016/11/bolsonaro-diz-no-conselho-de-etica-que-coronel-ustra-e-heroi-brasileiro.html. Acesso em: 2 mar. 2019.

BRASIL. Constituição da República Federativa do Brasil de 1988. Disponível em: http://www.planalto.gov.br/ccivil_03/Constituicao/Constituicao.htm. Acesso em: 16 out. 2018. 
BRASIL. Decreto n. 678, de 6 de novembro de 1992. Disponível em: http://www.planalto.gov.br/ccivil_03/decreto/d0678.htm. Acesso em: 16 out. 2018.

BRASIL. Decreto $n$. 7.030, de 14 de dezembro de 2009. Disponível em: http://www.planalto.gov.br/ccivil_03/_ ato2007-2010/2009/decreto/d7030.htm. Acesso em: 16 out. 2018.

BRASIL. Lei n. 6.683, de 28 de agosto de 1979. Disponível em: http://www.planalto.gov.br/ccivil_03/leis/L6683. htm. Acesso em: 14 out. 2018.

BRASIL. Lei n. 10.559, de 13 de novembro de 2002. Disponível em: http://www.planalto.gov.br/ccivil_03/ LEIS/2002/L10559.htm. Acesso em: 16 nov. 2018.

BRASIL. Lei n. 12.528, de 18 de novembro de 2011. Disponível em: http://www.planalto.gov.br/ccivil_03/_ Ato2011-2014/2011/Lei/L12528.htm. Acesso em: 14 nov. 2018.

BRASIL. Secretaria Especial dos Direitos Humanos. Comissão Especial sobre Mortos e Desaparecidos Políticos. Direito à verdade e à memória: Comissão Especial sobre Mortos e Desaparecidos Políticos. Brasília: Secretaria Especial dos Direitos Humanos, 2007.

BRASIL. Supremo Tribunal Federal. ADPF n. 153. Relator: min. Eros Grau. Julgado em 29 de abril de 2010, DJE no 83, divulgado em 10 maio 2010. Disponível em: http://redir.stf.jus.br/paginador/paginador.jsp?docTP=AC\&do$\mathrm{CID}=612960$. Acesso em: 14 maio 2018.

BUENO, Tomás Balladolid. Justicia de Transición y justicia restaurativa. In: SOUSA JUNIOR, J. G. de. O Direito Achado na Rua. v. 7: Introdução Crítica à Justiça de Transição na América Latina. Brasília: UnB. 2015. p. 325-328.

CANTON, Santiago. Leis de anistia. In: REÁTEGUI, F. (org.). Justiça de Transição: manual para a América Latina. Brasília: Ministério da Justiça; Nova York: ICTJ, 2011. p. 263-290.

CHARLEAUX, J. P. El Salvador engrossa lista de países que derrubaram a lei de anistia. Nexo Jornal [on-line]. Disponível em: https://www.nexojornal.com.br/expresso/2016/07/26/El-Salvador-engrossa-lista-de-pa\%C3\%ADses-que-derrubaram-a-lei-de-anistia. Acesso em: 4 nov. 2018.

COMISSÃO DE FAMILIARES DE MORTOS E DESAPARECIDOS POLÍTICOS. Dossiê dos mortos e desaparecidos políticos a partir de 1964. Recife: Companhia Editora de Pernambuco, 1995.

CONSELHO FEDERAL DA ORDEM DOS ADVOGADOS DO BRASIL. Petição inicial. Arguição de descumprimento de preceito fundamental n. 153. Disponível em: http://www.stf.jus.br/portal/geral/verPdfPaginado.asp?i$d=330654 \&$ tipo=TP\&descricao=ADPF\%2F153. Acesso em: 22 out. 2018.

CORTE INTERAMERICANA DE DIREITOS HUMANOS. Caso Almonacid Arellano e outros Vs. Chile. Sentença de 26 de setembro de 2006. Disponível em: http://www.corteidh.or.cr/docs/casos/articulos/seriec_154_esp.pdf. Acesso em: 5 nov. 2018.

CORTE INTERAMERICANA DE DIREITOS hUMANOS. Caso Barrios Alto Vs. Peru. Sentença de 14 de março de 2001. Disponível em: http://www.cnj.jus.br/files/conteudo/arquivo/2016/04/092b2fec1ad5039b26ab5f98c3f92118. pdf. Acesso em: 5 nov. 2018.

CORTE INTERAMERICANA DE DIREITOS hUMANOS. Caso Gomes Lund e Outros Vs. Brasil. Sentença de 24 de novembro de 2010. Disponível em: http://www.corteidh.or.cr/docs/casos/articulos/seriec_219_por.pdf. Acesso em: 23 set. 2018.

CORTE INTERAMERICANA DE DIREITOS HUMANOS. Caso Herzog Vs. Brasil. Sentença de 15 de março de 2018. Disponível em: http://www.corteidh.or.cr/docs/casos/articulos/seriec_353_por.pdf. Acesso em: 4 out. 2018.

DE FREITAS CRUZ, S. R. Análise crítica do conceito de anistia na lei 6.683/1979 e o conceito de perdão na ADPF 153: hermenêutica crítica. Belo Horizonte: Edições Superiores. 2018.

DE STUTZ E; ALMEIDA, E. (Org.). Justiça de transição no Brasil - apontamentos. Curitiba: CRV. 2017.

DE GREIFF, Pablo. Transitional Justice, Security, and Development: Security and Justice Thematic Paper. Washington: World Bank, 2011.

ÉBOLI, E. Governo Temer suspende pedido de desculpas às vítimas da ditadura. Gazeta do Povo [on line]. Disponível em: https://www.gazetadopovo.com.br/politica/republica/governo-temer-suspende-pedido-de-desculpas-as-vitimas-da-ditadura-13klbj0uqdjrOni19mc8dbi0w/. Acesso em: 16 fev. 2019.

FERNANDES, M. Corte Interamericana de Direitos Humanos condena Brasil por morte de Vladimir Herzog. Huffpost Brasil [on-line]. Disponível em: https://www.huffpostbrasil.com/2018/07/04/corte-interamericana-de-direitos-humanos-condena-brasil-por-morte-de-vladimir-herzog_a_23474860/. Acesso em: 4 nov. 2018. 
FIX-ZAMUDIO, H. La Protección Judicial de los Derechos Humanos en Latinoamérica y en el Sistema Interamericano. Revista do Instituto Interamericano de Derechos Humanos, San José, n. 8, jul./dez. 1988. Disponível em: http://biblioteca.corteidh.or.cr:8070/alipac/NJABKASOQHMQNRCOSZOT-00019/find=-simple?1C=28\%\&1VLa+Protecci\%C3\%B3n+Judicial+de+los+Derechos+Humanos+en+Latinoam\%C3\%A9rica+y+en+el+Sistema+Interamericano\&C2=\%29\&F1=WRD\&x=64\&y=16.

GATHE, G. O legado da comissão da anistia e os riscos de uma gestão conservadora. História da Ditadura. Disponível em: https://www.historiadaditadura.com.br/destaque/o-legado-da-comissao-de-anistia. Acesso em: 4 nov. 2018.

GIROUD, F. Gais-z-et-contents. Paris: Editeur Seuil, 1997.

GODOY, M.; NOSSA, L. Brasil é condenado por assassinato de Herzog. O Estadão de S. Paulo [on-line]. Disponível em: https://politica.estadao.com.br/noticias/geral,brasil-e-condenado-por-assassinato-de-herzog,70002387409. Acesso em: 4 nov. 2018.

GONZALES, J. Sarney defende sigilo eterno de documentos para não "abrir feridas". Estadão [on-line]. Disponível em: https://politica.estadao.com.br/blogs/radar-politico/sarney-defende-sigilo-eterno-de-documentos-para-nao-abrir-feridas/. Acesso em: 20 fev. 2019.

GUSTIN, M. B. de S.; DIAS, M. T. F. (Re)pensando a pesquisa jurídica: teoria e prática. Belo Horizonte: Del Rey, 2010.

HOLLANDA, C. B. de. et al. Justiça de Transição e Direitos Humanos na América Latina e na África do Sul. Revista $O A B / R J$, Vol. 25, n. 2, p. 55-75, 2010.

JORDÃO, F. P. Dossiê Herzog. São Paulo: Global, 2005.

LINS E SILVA, T. A Construção da Anistia. Espaço Jurídico, Revista da Universidade do Oeste de Santa Catarina, Chapecó, v. 12, n. 2, p. 247-263, jul./dez. 2011.

LUCAS, D. C.; OLIVEIRA, C. D. de. A justiça de transição no Brasil: elementos para pensar a democracia na América Latina. Pensar, Fortaleza, v. 21, n. 3, p. 906-933, set./dez. 2016.

MEMÓRIAS DA DITADURA. Harry Shibata. Disponível em: http://memoriasdaditadura.org.br/biografias-da-ditadura/shibata/index.html. Acesso em: 16 out. 2018.

MEMÓRIAS DA DITADURA. Manoel Fiel Filho. Disponível em: http://memoriasdaditadura.org.br/biografias-da-resistencia/manoel-fiel-filho/index.html. Acesso em: 14 fev. 2019.

MARKUN, P. Meu querido Vlado: a história de Vladimir Herzog e do sonho de uma geração. Rio de Janeiro: Objetiva, 2015.

MENDÉZ, Juan E. Responsabilização por abusos do passado. In: REÁTEGUI, F. (org.). Justiça de Transição: manual para a América Latina. Brasília: Ministério da Justiça; Nova York: ICTJ, 2011. p. 193-226.

MEYER, E. P. N. Responsabilização por graves violações de direitos humanos na ditadura de 1964-1985: a necessária superação da decisão do Supremo Tribunal Federal na ADPF n. 153/DF pelo Direito Internacional dos Direitos Humanos. 2012. Tese (Doutorado em Direito) - Faculdade de Direito, Universidade Federal de Minas Gerais, Belo Horizonte, 2012.

OSMO, C. O Judiciário brasileiro diante dos crimes da ditadura: entre a imprescritibilidade civil e a anistia penal. In: SEMINARIO INTERNACIONAL POLÍTICAS DE LA MEMORIA, 9., Buenos Aires. 2016. Disponível em: http://conti. derhuman.jus.gov.ar/2016/11/seminario/mesa_18/osmo_mesa_18.pdf. Acesso em: 4 nov. 2018.

OST, F. O tempo do direito. Tradução Maria Fernanda Oliveira. Lisboa: Instituto Piaget. 1999.

PEREIRA, A. W. Ditadura e repressão: o autoritarismo e o estado de direito no Brasil, no Chile e na Argentina. São Paulo: Paz e Terra. 2010.

RAMOS, A. de C. Principais aspectos da promoção de direitos humanos na Organização dos Estados Americanos. Hemisferio: Revista del Colegio Interamericano de Defensa, Washington, v. 3, p. 91-112. 2017.

RAMOS, A. de C. Supremo Tribunal Federal Brasileiro e o Controle de Convencionalidade: levando a sério os tratados de Direitos Humanos. Revista da Faculdade de Direito da Universidade de São Paulo, v. 104, p. 241-286, jan./dez. 2009.

REÁTEGUI, F. (org.). Justiça de transição: manual para a América Latina. Brasília: Comissão de Anistia, Ministério da Justiça; Nova Iorque: Centro Internacional para a Justiça de Transição, 2011.

SANTIAGO, T. Família de Vladimir Herzog recebe novo atestado de óbito. G1 [on-line]. 2013. Disponível em: http://g1.globo.com/sao-paulo/noticia/2013/03/familia-de-vladimir-herzog-recebe-novo-atestado-de-obito. html. Acesso em: 20 fev. 2019. 
SECURITY COUNCIL OF UNITED NATIONS. Report of the Secretary-General: The rule of law and transitional justice in conflict and post-conflict societies. 2004. Disponível em: http://www.un.org/en/ga/search/view_doc.asp?symbol=S/2004/616. Acesso em: 30 maio 2018.

SILVA, J. A. da. Curso de Direito Constitucional Positivo. São Paulo: Malheiros, 2006.

SILVA FILHO, J. C. M. da. O julgamento da ADPF 153 pelo Supremo Tribunal Federal e a Inacabada Transição Democrática Brasileira. In: RAMOS FILHO, Wilson (org.). Trabalho e regulação: as lutas sociais e as condições materiais da democracia. Belo Horizonte: Fórum, 2012.

SKIDMORE, T. Brasil: de Castelo a Tancredo. Rio de Janeiro: Paz e Terra, 1994.

SOUSA JUNIOR, J. G. de. O Direito achado na rua. Vol. 7: introdução crítica à justiça de transição na América Latina. Brasília: UnB, 2015.

URUGUAI: justiça derruba lei que impedia prescrição de crimes da ditadura. Terra [on-line]. Disponível em: https://www.terra.com.br/noticias/mundo/america-latina/uruguai-justica-derruba-lei-que-impedia-prescricao-de-crimes-da-ditadura,7cc2c35e3ecfc310VgnCLD2000000ec6eb0aRCRD.html. Acesso em: 16 nov. 2018.

VAN ZYL, Paul. Promovendo a justiça transicional em sociedades pós-conflito. In: REÁTEGUI, F. (org). Justiça de Transição: manual para a América Latina. Brasília: Ministério da Justiça; Nova York: ICTJ, 2011. p. 47-72.

VEIGA, E. Missa em homenagem a Vladimir Herzog na Catedral da Sé. O Estadão de S. Paulo [on-line]. Disponível em: https://sao-paulo.estadao.com.br/noticias/geral,missa-em-homenagem-a-vladimir-herzog-na-catedral-da-se,1624022. Acesso em: 16 out. 2018.

VENTURA, D. de F. L. A interpretação judicial da Lei de Anistia brasileira e o Direito Internacional. Revista Anistia: Política e Justiça de Transição, Brasília, Ministério da Justiça, n. 4, p. 196-227, 2010. 